\title{
'Screaming with Joy': Allen Ginsberg and the Politics of Queer Masochistic Performativity
}

\author{
Anil Pradhan \\ PhD Scholar, Department of English, Jadavpur University, Kolkata, India \\ Email: anilpradhan.eng.rs@jadavpuruniversity.in
}

\begin{abstract}
Allen Ginsberg's Howl presents a complex idea of queer identity politics restructuring American urbanity. In a de Certeauan portrayal of 'queer' sexual encounters, the actors tend to subvert notions of the heteronormative hegemony over sexuality, sexual bodies, and masculinities. The writing back by the marginalised sexual 'Others' employs the agency of representing pain as liberating, subversive, and pleasurable. These ecstatic performances reveal gender and sexuality as 'performative,' contributing towards a construction of a 'homosexual masculinity' which is subversive of heteronormative politics. However, there can be located a counter-subversion at work in this portrayal of queer masculinity by virtue of its drawing from the very heteronormative constructs that it intends to subvert. Nevertheless, the agency of a Deleuzian 'queer masochism' entailed in a Butlerian queer performativity can be inferred as a potential strategy for refashioning queer literary politics. This paper attempts to interrogate this very discursive queer identity and performative politics in Ginsberg's poetry.
\end{abstract}

Keywords: Ginsberg, Howl, queer, performativity, masochism, public, space

I saw the best minds of my generation destroyed by madness,

starving hysterical naked,

who let themselves be fucked in the ass by saintly motorcyclists,

And screamed with joy, (Ginsberg, 2009, p. 1, 4)

What is it with these men who, despite being 'destroyed by madness' and 'starving hysterical,' let themselves be subjected to pain and yet scream and howl with joy and pleasure? Are they simply challenging the heteronormative politics of sexual hegemony or are they discursively proclaiming their right to be queer and yet be able to extract pleasure out of their pained existence in the society of the mid-20 ${ }^{\text {th }}$ century America?

These lines quoted above come from one of the representative pieces of the literature of the Beat Generation in the American post-WWII era. The lines exemplify the explicit portrayal of the contemporary human condition, sexual liberation, and queer exploration celebrated by the Beat literary revolution. Allen Ginsberg's (1926-1997) celebrated and controversial poem Howl

(C) AesthetixMS 2020. This Open Access article is published under a Creative Commons Attribution Non-Commercial 4.0 International License (http://creativecommons.org/licenses/by-nc/4.0/), which permits non-commercial re-use, distribution, and reproduction in any medium, provided the original work is properly cited. For citation use the DOI. For commercial re-use, please contact editor@rupkatha.com. 
(1955-56) - a key text from one of the most important literary figures of this tradition - portrays images of homosexual subjects performing subversive acts that are otherwise condemned by the hetero-normative and hetero-patriarchal society and degraded to sinful pain and futility. Ginsberg's poetry can be read and re-read to depart from and arrive at multiplicitous interpretations of the challenge to the normative, and as Jonah Raskin reminds us, through the continued re-visitation of Howl, one might as well realise what Ginsberg explained about his poem as being an "emotional time bomb that would continue exploding" (Raskin, 2004, p. xx). In the process of the queering of the "pain-pleasure principle," Ginsberg dismantles the idea of the heteronormative monopoly on gender and sexuality, and in doing so, Ginsberg's poems seem to carve out non-heteronormative homoerotic spaces for themselves by projecting the politics of the private into the public in urban space through what Judith Butler terms 'gender performativity. ${ }^{\text {,ii }}$ This screaming with joy, while partaking in homosexual erotic acts, by Ginsberg's performers challenges the presumed constructs of heteronormative masculinity and in turn, constructs a certain non-normative politics of gay/queer masculinity. Yet, in doing so, it seems that these homosexual identities tend to model themselves on heteronormative constructs of sex and masculinity and are left struggling to unchain themselves from the grasp of what Butler calls the 'heteronormative matrix. ${ }^{\text {,ii }}$

However, the politics of 'queer masochism' that the homosexual acts employ eventually renders the queer sexual subject with a subversive agency that manages to embody a queer opposition to the hegemonic discourse of heteronormativity and masculinity. This paper attempts at interrogating how Ginsberg's Howl, and other poems, portray queer subjectivity and its gender performativity through sexual acts in the public space by subverting existing norms by creating homosexual spaces but are at the same time trapped within the norms it tends to subvert. It also attempts enquiring into the agency of pain and pleasure related to such queer gender performativity and how queer masochism eventually sustains the subversion of heteronormativity and hegemonic masculinity and an assertion of queer body and identity politics through discursive queer performativity.

\section{Screaming Out: Queer Subversion of Heteronormative Politics}

The passage in Howl that voices the unrestricted assertion of queer sexual identity also exposes the reality of queer lives in the urban spaces of the mid-twentieth century America, stated as follows:

I saw the best minds of my generation destroyed by madness,

$[\ldots]$

who bit detectives in the neck and shrieked with delight in policecars for committing no crime but their own wild cooking pederasty and intoxication,

who howled on their knees in the subway and were dragged off the roof waving genitals and manuscripts,

who let themselves be fucked in the ass by saintly motorcyclists, and screamed with joy,

$[\ldots]$ 
who balled in the morning in the evenings in rosegardens and the grass of public parks and cemeteries scattering their semen freely to whomever come who may, (Ginsberg, 2009, p. 3-4)

Ginsberg freely uses uncensored words forming a liberating assault on the restrictive stereotypes surrounding sexuality, pain, and pleasure constructed by the heteronormative and the hegemonic. This sexualised form of liberation that Ginsberg's poetic agency helps voice is contingent with the Beat philosophy of revolutionary sexuality. Through the performance of promiscuously queer acts in the public spaces of the cityscape, Ginsberg paints a picture of the sexual emancipation of the repressed and marginalised identities of his times. Within such a literary politics, Ginsberg envisages his 'queer' characters as being both located in discernible every day urban spaces and also challenges the boundaries and expectations of the normative society through such sexual and bodily performances of a rebellious nature.

Additionally, it is worth interrogating how Ginsberg himself interprets his literary projection of sexual liberation to be a political statement for the heteronormative society. Ginsberg, in Howl: Original draft facsimile, transcripts, and variant versions, has annotated the specific line as such:

'And screamed with joy': Popular superstition had it that one screamed with pain in such a circumstance. Howl's enthusiastic version is more realistic. For its time the iconoclastic 'shocker' of the poem, this verse reversed vulgar stereotype with a statement of fact. (2006, p. 126, emphasis added)

This 'iconoclastic shock' that Ginsberg posits in the poems such as Howl manages to queer contemporary notions and expectations of a heteronormative and homophobic American society. Such an unthought-of possibility invests gay masculinity with a subversive agency that functions as a reckoner for the subterranean realities of queer sexualities. This queer subversion is agentialised through a discursive inversion of the pain-pleasure principle by and through a poetic politics of queer desiring, eroticism, and performance. By taking delight in what is considered a disgusting and punishable sex act, these lines re-interpret and re-present to the readers queer male subjectivities exemplified by their shrieks, screams, and howls. Talking about gay masculinity vis-a-vis Howl, Dagmar Van Engen comments that the lines "[...] queer homophobic construction of gay identity through refiguring the painful and perverse as an instance of pleasure" (2012, p. 8). Similarly, interpreting the 'saintly motorcyclists' lines from Howl in terms of rebellion and liberation, Raymond Jean Frontain claims that anal eroticism was Ginsberg's "highest form of celebration, emancipation and release" (as cited in Van Engen, 2012, p. 4). When men can find pleasure in such acts, the hetero-normative claims of masculinity tend to lose their grip, resulting in a fluidity of gender identities - something that both embodies and problematises the contexts of madness and suffering in Howl. In his proselytising of queer sexual desires and activities, Ginsberg announces, and as Byrne Fone notes, that "happiness and enlightenment, not pain and degradation could be the result of homosexual sex" (2000, p. 402).

A crucial aspect of the poem is that such queerly pleasurable acts are being shown to take place openly in public spaces in the metropolis. Much like the 'the personal is the political' of second-wave feminism of the 1960s, 'the private is the public' has gradually become the adage in contemporary queer politics surrounding identities, sexualities, eroticisms, and rights; Ginsberg's Howl seems to be one of the very first literary harbingers of this politics of the 'personal-in-thepublic.' In its various transgressions and subversions, Howl does not limit sex within its designated domestic space, but rather departs from the heterosexual (and hetero-normative) injunction on what can be done, where it can be done, and how it can be done. This reinterpreted 
sense of queer sexuality is made visible throughout the urban spaces that feature in his poem, not restricting to just police cars, subways, and roofs but also in gardens, public parks, graveyards, hallways, diners, empty lots, and movie theatres. These subversive acts strive to create a queer space of its own in the city, as opposed to the normative, generally private sexual space of the heterosexuals. Lawrence Knopp's discussions on the intersections of sexuality and urban spaces project the idea that the sexuality of the city can be "described as an eroticisation of many of the characteristic experiences of modern urban life: anonymity, voyeurism, exhibitionism, consumption, authority (and challenges to it), tactility, motion, danger, power, navigation and restlessness" (1995, p. 138). Contextually, the processes of the 'sexual coding' of urban spaces "emphasise both erotic and more functional conceptions of sexuality," are "connected to power relations," and are "fiercely contested" (Knopp, 1995, p. 139).

Similarly, in a queer access, manipulation, and contestation of spatial possibilities vis-à-vis sexual re-coding of same-sex eroticism, Ginsberg's queer performers function as queer practitioners of the city. In their queer voyeurism of the city's 'general' spaces, Ginsberg's 'queer' subjects manage to access constructed spaces that have been "shaped out of fragments of trajectories and alterations of spaces" (de Certaeu, 1984, p. 94). What Michel de Certeau theorises as a discursive consumption of alternative spaces within the fragmented localisation of the city's permissible manipulation can be utilised to understand the politics of how a queer urban spatial appropriation by Ginsberg's performers works. The multiplicity of the queer appropriation of the liminal-within-the-visible space coagulates into a plurality - one where the strategic localisation results into a political spatialisation of queer subcultural activities. In this process is entailed a strategic execution of the queer city-practitioners' travels, or to say traversals, whereby in a de Certeauan analogy, Ginsberg's queer traversers' enunciation of the spatial pathways of the city promotes an inherent mapping of the city on queer terms that make plausible uses of the urban conditions.

In this project of 'spatial capitation, iv literary narratives and the politics of narration, as that of Howl, function as the queer metaphorai through which a refashioning of spatial boundaries is executed, through which a spatialisation of the liminal is orchestrated and agentialised, and through which the city's places transform into queer lived spaces. In a de Certeauan reconstruction of the heteronormative space, the queer performers of Ginsberg's poem partake in a sexual performativity that navigates through the Foucauldian panopticon-like gaze of the heteronormative society and manage to functionalise a re-spatialisation of queer sexual desires into pleasure in the queer urbanity of American spaces, often bordering on queer masochism. More than an idea of queer risk-taking, the queering of public spaces in Howl manifests itself as an assertive challenging of spatial politics of the 'normal' and the 'hegemonic' and provides a transformative negotiation with the permissible, specifically targeting and centring non-heteronormative desires, love, and dangerous romance between, and among, men and the very idea of hegemonic masculinity.

What can be considered as a parody of the structured heteronormative gender and hegemonic masculine identities results in a 'fluidity' of sexual identities. Judith Butler, in Gender Trouble: Feminism and the Subversion of Identity, talks about a "perpetual displacement" constituting "a fluidity of identities that suggests an openness to resignification and recontextualisation" (2002, p. 176). Butler claims that "parodic proliferation deprives hegemonic cultures and its critics of the claim to naturalized or essentialist gender identities" (2002, p. 176). Furthermore, as Bell and Valentine comment in the context of the Butlerian agency of performing 'queer'-ness in public spaces, "straightness of our streets is an artefact, not a natural fact, and [...] 
non- or antiheteronormative acts make this clear by making it queer" (1995, p. 17). Challenging the hegemonic heteronormative 'straightness' of streets as an 'artefact,' Ginsberg's Howl and its descriptions of homosexual acts push against the boundaries of the body and the limits of the hegemonic vis-à-vis both sexuality and masculinity. Drawing from Mary Douglas' Purity and Danger, Butler also says that "anal and oral sex among men clearly establishes certain kinds of bodily permeabilities unsanctioned by the hegemonic order" (2002, p. 168). Talking about the "false stabilization of gender in the interests of the heterosexual construction and regulation of sexuality within the reproductive domain," Butler points out how homosexuality exposes "the regulatory ideal of hegemonic heteronormativity as fiction" (2002, p. 173). Ginsberg's description of homosexual pleasure-in-pain acts tend to work towards a similar purpose. Through a performance of such sexual acts, they perform their queer gender identities. Butler constructs gender as performativity, a repetition of gendered actions, as she writes is Gender Trouble:

Gender ought not to be construed as a stable identity or locus of agency from which various acts follow; rather, gender is an identity tenuously constituted in time, instituted in an exterior space through a stylized repetition of acts which are internally discontinuous [...]. (2002, p. 179, emphases mine)

Drawing from such an understanding of Butler's idea of 'gender performativity,' I contend that Ginsberg's subversion is achieved through a queering of performativity, which is showcased in his characters' involvement in a non-normative, subversive, public and queer repetition of same-sex acts, and if fact, the enjoyment of the same. Portraying sexuality and gender as denaturalised, a "stylized repetition" of such acts by the homosexual and queer subjects in Ginsberg's Howl constitutes a gender subjectivity, at once, as normal as the heterosexuals' and at the same time subversive of the whole idea of the heterosexual normativity and hegemonic masculinity. This "performative subversion" (Butler, 2002, p. 163-180) by those who shriek and scream with joy is brought out by bold public confessions and brings about a "performative accomplishment" (Butler, 2002, p. 179) which, according to Anne Hartman, uses a "remodelled confessional mode to articulate dissident sexuality," and thus, constructs a "counter-hegemonic homosexual public" (Hartman, 2005, p. 48).

In this context, one could find Ginsberg's confessions in Howl as having knowledge about such dissident, yet elated homosexual practices, and their actors, endorsing a politics of comingout of the closet, into the public space. A confession which was supposed to be private, spills out into the public and asserts and demands as much legitimacy as any heteronormative assertion of sexual and gender identity. In fact, as Raskin notes, for Ginsberg, "Howl was a literal 'coming out of the closet' and an 'acknowledgement of the basic reality of homosexual joy" (2004, p. xx). Furthermore, through a textualisation of the 'private' body, Ginsberg valorises his characters' dissidence as a proclamation of the legitimacy of their individual desires in the public. This, he does by investing a queer subjectivity in the idea of extracting pleasure from pain which is otherwise relegated to the margins of socio-political validity by the society. However, on a different note, these subversive performances by Ginsberg's characters also howl out the loss and melancholia within themselves.

\section{Screamed Upon: The Counter-Politics of Discursive Heteronormativity}

James Breslin has asserted that Howl is charged with strong feelings of loss and that the poem reacts to loss by "idealizing, mythologizing the lost object" (1977, p. 87) - the lost object being a validity of the homosexual identity. In a similar context, Abraham and Torok have talked about a 
"state of disavowed or suspended grief in which the lost object is magically sustained 'in the body' in some way" (as cited in Butler, 2002, p. 86.) Discussing about such "incorporation" (Abraham and Torok's term) as a way of accomplishing gender identity, Butler points out that "disavowed homosexual love is preserved through the cultivation of an oppositionally defined gender identity" (2002, p. 88-89). She goes on to assert that "disavowed male homosexuality culminates in a heightened or consolidated masculinity" (2002, p. 89). Ginsberg can be seen to achieve a certain heightened masculinity in his poems' queer masculine identity politics, always already subverting the identity politics of the instituted and naturalised hegemony of heterosexual body. Though this is achieved by Ginsberg's characters in their screams of joy, one encounters another aspect of this liberation in the later lines of the poem:

Moloch! Moloch! Nightmare of Moloch! Moloch the loveless! Mental Moloch! [...]

Moloch the incomprehensible prison!

$[\ldots]$

Moloch whose name is the Mind!

Moloch in whom I sit lonely! Moloch in whom I dream Angels! Crazy in Moloch! Cocksucker in Moloch! Lacklove and manless in Moloch!

Moloch who entered my soul early! Moloch in whom I am a consciousness without a body! Moloch who frightened me out of my natural ecstasy! Moloch whom I abandon! Wake up in Moloch! [...](Ginsberg, 2009, p. 8-9)

The speaker talks about "Moloch," which I read as the oppressive, Capitalist and heteronormative society, being the "mind' itself and as incomprehensible as a prison, which is a part of the self itself, where he/she sits trapped, "cocksucker," "lacklove" and "manless," waiting for the "lost object" to be somehow restored, trying to break away, and yet waking up in the very pit of what is termed "Moloch." This entails within itself an implicit idea of the homosexual 'Other' being trapped within the heterosexual 'Self despite all the howling and screaming with joy of the gay masculine liberation. The individual who was striving and was almost victorious in subverting heteronormative gender politics, seem to be eventually transformed from the queer 'non-subject' back to being a social 'subject' or to use Julia Kristeva's term, the "abject." Butler talks about the "abject," as derived from Kristeva's discussions on abjection in Powers of Horror, as designating that "which has been expelled from the body, discharged as excrement, literally rendered 'Other'" (as cited in Butler, 2002, p. 170). The inner/outer coherence constituting gender identities are definitely challenged by such homosexual acts as Ginsberg talks about, thus problematising and subverting the entire idea of monolithic heteronormative identities and the validity of its hegemonic politics. The heterosexual 'Self becomes the homosexual 'Other,' and Ginsberg portrays such transforming acts in the realm of the public space. Yet again, it can also be understood that such an Otherisation leads to the 'Self all over again, as was evident from the "Moloch" passage quoted earlier. It can be inferred that in the process of becoming the 'Other' and portraying the heterenormative as the "Abject" through public homosexual acts, the performers are eventually rendered trapped within the 'Self.'

However, Butler, in Undoing Gender, is of the view that the 'Self' and the 'Other' are always implicated in each other (see 2004, p. 19-21). The binary of male/female gender identity is again superimposed upon by the binary of the male-role playing/female-role playing subjects. The 
dominant/submissive roles play between the characters that Ginsberg so very much celebrates in Howl, can be seen to be eventually trapped in the heteronormative binary itself. To quote Butler, there is an "expulsion of alien elements, but the alien is effectively established through their expulsion" (2002, p. 169); in this context, the alien would be the 'heteronormative' implicated within the 'homosexual'/'queer.' Discussing the politics of the Beat Generation, Catharine Stimpson comments how in the ideology of the Beats, men took the role of women. She talks about two pertinent points: (1) how male homosexuals portrayed dominant/submissive role playing identities; and (2) how men could be treated as commodities. She writes this:

In Beat writing, sodomy vividly emblemizes such a coupling. The sodomizer is dominant, powerful, potentially cruel, and masculine; the sodomized submissive, powerless, potentially a victim, and feminine. Of the Beats, Ginsberg most fully inscribes a sodomy that incorporates sado-masochistic traits. He can pretend to be a torturer who lasciviously inspects naked culprits, but more often he plays bottom in his games. (1983, p. 380)

On a biographical note, Stimpson also talks about a similar re-subversion in the GinsbergOrlovsky relationship (Peter Orlovsky was Ginsberg's partner till the latter's death):

In his pact with Orlovsky, Ginsberg also perpetuated an odd mind/body split. He masculinized the roles of intellectual and poet, and assumed them for himself. Though he was artistic, Orlovsky was to be a golden wondrous body that could, in bed, feminize the intellectual and poet. (1983, p. 390)

In a way, it can be noted how even a radical Ginsberg couldn't wholly transcend gender-ed norms. He seems to both transgress against and again accept the gendered patriarchal heteronormative norms and so do those who screamed with joy but eventually woke up in "Moloch." Talking about how the marginalised/homosexual discourse gets absorbed into the mainstream heteronormative, Nick Selby avers that however rebellious the rebel heroes of Ginsberg's poem are, they are rebellious in "a very traditional way" (1996, p. 65). This can be discussed in terms of how sexuality emerges as the new "commodity" for the heteronormative Capitalist America, drawing from Stephen Heath's idea of the "Sexual Fix," and also how the "gay heroes of Ginsberg's text are being absorbed into the popular heroism of straight America." (Selby, 1996, p. 64).

In an interview conducted by Lisa Meyer, Ginsberg's answers present an indirect, though unclear, reference to sexual conformity:

Meyer: 'Is the phrase "putting my queer shoulder to the wheel" in your poem America referring just to your sexuality or also to a sense of non-conformity?'

Ginsberg: 'It's a pun. My unusual shoulder. My natural shoulder, my queer shoulder, my shoulder that would be considered queer by others but is my strong shoulder. It's also a mockery. It's a macho trait: put your shoulder to the wheel. I'm putting my faggoty shoulder to the wheel because America needs that.' (1997, p. 22)

What can be read into these statements is that the macho homosexual 'Other' is again placed, knowingly or unknowingly, willingly or unwillingly, into the heteronormative 'Self' of the American society and the 'abject' becomes the 'subject' eventually; similarly the 'queer machos' screaming with joy in Howl, wasting time and energy in the machinery of the "Mental Moloch." Thus, it can be inferred how queer identity politics is asserted boldly in Ginsberg's Howl and at the same time is seen to be not entirely free from the claws of heteronormativity. In other words, the characters screaming with joy are 'gay' in their denaturalised discourse of queer-ness but at the same time, are not entirely liberated away from the hegemonised heteronormative discourse. 
Ginsberg claims of his idea in Howl as such: "In it I am leaping out of a preconceived notion of social 'values,' following my own heart's instincts-allowing myself to follow my own heart's instincts, overturning any notion of propriety, moral 'value,' superficial 'maturity"' (Ginsberg \& Miles, 2006, p. 152, emphasis author's). On a different note, here it can also be read that, consciously or unconsciously, Ginsberg and his characters are trapped within the very notions of social 'values' which they so vehemently tried to subvert with their public acts of sexual non-conformity. The characters are not being able to fully comprehend and liberate themselves from the heteronormative matrix, and Ginsberg finds these "best minds" of his "generation destroyed by madness, starving hysterical naked" (2009, p. 1). Ginsberg and those "best minds" are left elated in such a quest of subverting the heteronormative but are also bewildered at finding themselves "lying mad" within the very machinery of "Moloch" they nearly subverted. Whatever level of non-heteronormative homosexuality and masculinity that these characters and their "performative subversion" (Butler, 2002, p. 163-180) led to re-construct is seen as a myth, an illusion, leaving them, ironically, in the 'incomprehensible prison' of the very heteronormative matrix they so much hate and despise.

\section{Screaming Back: Queer Masochism Asserting and Sustaining Queer Subjectivity}

However, Raskin reminds us that despite the sense of despair and gloominess embedded by Ginsberg in Howl, he indeed was hopeful of joy, of a possibility of social utopia (see 2004, p. 22). In a similar vein, contrary to the inference in the previous section, in a different discourse of identity politics, one can read the recourse to queer masochism in Ginsberg's poems as a strategic assertion of queer sexuality and agency of queer sexual performance; one such example can be the poem "Please Master." In "Please Master," Ginsberg portrays a complicated idea of intimate masochism between men, rejecting views of homosexual acts as unpleasantly violent, showing them, instead, as moments of loving intimacy:

please master drive me thy vehicle, body of love dops, sweat fuck

body of tenderness, Give me your dog fuck faster

please master make me go moan on the table

Go moan O please master do fuck me like that

$[\ldots]$

till I loosen my asshole a dog on the table yelping with terror delight to be loved (Ginsberg, 2007, p. 553-554)

In the context of this poem, it is important to interrogate the personal references to

Ginsberg's life Raskin informs about. Raskin claims that Ginsberg's "poetry and his homosexuality were inextricably linked; they both went to the core of his being" (2004, p. 56-57). Given the understanding that Howl is a representative outcome and liberation of Ginsberg's personal struggles with his familial problems, capitalist politics, and sexual identity and homoerotic desires (Raskin, 2004, p. 34-35), the poetic references to his personal struggles in "Please Master" reveal another side of the story. Raskin informs us that the poetic passion "Please Master" is in reference to Allen Ginsberg's 'queer' relationship with Neal Cassady (2004, p. 77). In the context of Ginsberg's relationship with Neal Cassady, the poem "Many Loves" also celebrates their passionately erotic encounter and tender lovemaking: "Neal Cassady was my animal: he brought 
me to my knees and taught me the love of his cock and the secrets of his mind" (Ginsberg, 2007, p. 178). Near the end of the poem, as Raskin highlights, Ginsberg hints at the dark side of their sexuality - "I made my first mistake, and made him then and there my master" (Ginsberg, 2007, p. 180). In this context, Raskin notes that "it wasn't until after Cassady's death in 1968 that Ginsberg described their sadomasochist relationship in the poem 'Please Master” (2004, p. 77). The poem reveals an intensity of pleasurable masochism that defies limitations of debasing the body, for even as the man begs to be incorporated in a ritual of violent sexual intercourse and animalistic passion, the poem ends on a positive and agential note of ecstasy enthused in passionate love between men.

To understand this agency of queer masochism in Ginsberg's poetry, I propose that Judith Butler's idea of subordination and disavowal be read in conjunction with Gilles Deleuze's idea of the power and agency of masochism. While drawing on the masochistic concepts of disavowal and reiteration, Butler, in The Psychic Life of Power, situates the subject at the crossroads of power, and asserts submission as a fundamental characteristic of subjection, linking subjection with submission (see Butler, 1997, p. 1-30). Butler claims that "Subjection' signifies the process of becoming subordinated by power as well as the process of becoming a subject" (1997, p. 2). However, the relation between subordination and disavowal is complex, for, "the subject's coherence is [itself] maintained by subordination and disavowal," where the "the stronger the disavowal, the more dependent and attached the subject becomes to the idea of its coherence and power" (Musser, 2005, p. 3). Thus, the sexual subject, though dependent on subordination, must strive towards a disavowal. When considered in the context of queer masculinity and masochism, the subordination-disavowal matrix illustrates the "potential for agency in subordination," which Butler draws on to "problematize conventional notions of [heteronormative] agency" (Musser, 2005, p. 3). I agree with Amber Jamilla Musser in considering that "Butler's suggestion that agency exists because power exists and that subordination is the condition for subjectivity hence agency" is "an idea that resonates with Deleuze's idea of agency in masochism" (Musser, 2005, p. 4).

Deleuze's masochism functions in an "intersubjective space between the dominant and the submissive as opposed to within a larger social context" (Musser, 2005, p. 4). Deleuze's idea of the 'free-indirect discourse' provides that "it is the way we think or approach [...] bodies" that constitutes the agency of descriptive language qua literature - through its "power to transform itself through sense" (Colebrook, 2007, p. 111-112). Subsequently, when considered in terms of the sexual body's performative agency, according to Deleuze, masochism considers the flesh to be "a valuable commodity in and of itself, not something excluded by discourse, but a necessary active part of subjectivity" (Musser, 2005, p. 4). This implicates the gender performativity of Butler's queer subject as partaking in an active politics of subjectivity assertion through transgressive sexual bodily acts. In this sense, masochism, thus, illustrates a "type of marriage between self, flesh, and desire; the masochist requires both flesh and desire to attempt a loss/refinding of self" (Musser, 2005, p. 5). Within this 'minoritarian politics' of the performative self, when considered in the domain of what Deleuze and Guattari term 'Minor Literature, ${ }^{\text {,i }}$ the performers of queer sexual masochism discursively advance from being a 'subjugated group' that "speaks as though it were representing, rather than forming, its identity" to a 'subject group' that "forms [itself] as an act of speech or demand, as an event of becoming" (Colebrook, 2007, 117). Thus, the eroticism embedded in queer gender performativity locates desire and flesh as central nodes in the practice of queer masochism and the agency of the queer masochist and points towards a discursive idea of queer subjectivity and its politics, non-hegemonic queer masculinity, and its literary/artistic representation. Musser explains this interrelation in these terms: 
The performative aspect of masochism depends on the locality of perception between performers. Beyond the broader notion of context, whereby certain acts take on meaning because of their location, perception, which operates on a more intimate level between performers, is significant because it creates the identities of the performers, even as they create the performance. In the ambiguous terrain between reality and fantasy, the self is figured as a potential [...] in the performative exchange. (2005, p. 4)

Thus, through a complementary theorisation of the agency of Deleuze's masochism and its influence upon Butler's sexual subjectivity, the idea of 'queer masochism' gains an empowered status, which when applied to queer masochism in Ginsberg's poetry, results in an alternative view of the inter-subversion of gender roles and queer gender performativity. Though, as discussed earlier, the queer sexual subject gets implicated within the heteronormative constructs of gender identities and their performance, I find that the queer masochism employed by Ginsberg provides those "who screamed with joy," notwithstanding their pain, with an agency queer sexual performativity. Notably, the idea of a dominant master/submissive duality in the dog figure in "Please Master" too subverts the whole logic of homosexuality-as-opposed-toheteronormativity, which the poem seems to assert through the depiction of pleasure-in-pain embedded in performative masochism. Those "who let themselves be fucked in the ass by saintly motorcyclists" in Howl, those who fused passionate sensuality with erotic submission in "Many Loves," and those who implored their sex masters to sodomise them without respite in "Please Master," all employ a discursive politics of queer masochism that renders their queer sexual performance as ultimately subversive of the heteronormative coda.

The 'pleasure-in-pain' that accompanies these subversive acts functions as a practical challenge to the notions of heteronormative sexual acts and even non-normative intimacy between men and the related constructs of masculinity. Their queer sexual performances aim towards and eventually render them what Thanem and Wallenberg term as 'becoming-both,' where the sodomiser and the sodomised both interchange and interplay power and agency, subverting the binaries of sexuality and gender (see 2010, p. 8). The 'queer masochism' in Ginsberg's poetry, thus, instead of re-inscribing sexual difference, portrays the longing for samesex desires and performance and through them, "instead of reinforcing sexual difference, [...] [strives] for sexual indifference" and transgresses heteronormatively gendered hegemonicmasculinist politics by "becoming not woman and not man, but both" (Thanem and Wallenberg, 2010, p. 8).

By drawing from the very concept of heteronormative masochism, the sexual performers in Ginsberg's poems validate their queer-ness through queer masochistic acts, which not only blur the borders between gender constructs but also invert the structures of sexual subjectivity, masculinist hegemony, and power politics. In a way, it's the sodomised in Ginsberg's poems, and not the sodomiser, who employs a sexual agency by being the one who control the sexual act and validate the enactment of a 'queer' masochism. In doing so, the stigmatised pain associated with homosexual acts gets transformed into a positive and empowering force of queer sexual assertion. This process queers Deleuzian masochism and functions in tandem with a subversive queer gender performativity, rendering the Butlerian queer sexual subject with an eventual agency which enables Ginsberg's characters to find their voices and scream with joy in all their pain and glory. It is this re-construction of queer pain into queer pleasure and the associated re-assertion of queer sexual identities that enables Ginsberg's actor-performers to retain the 'Other' within the 'Self' and vice versa and eventually improvise a way to survive in the maddening and nightmarish prison of Moloch. 


\section{Notes}

${ }^{\mathrm{i}}$ In Freudian psychoanalysis, the pleasure principle is the instinctual seeking of pleasure and avoiding of pain in order to satisfy biological and psychological needs. See Jean Laplanche and Jean-Bertrand Pontalis' discussion on the 'Pleasure Principle' in The Language of Psycho-analysis (1988), pages 322-325. In Beyond the Pleasure Principle (1921), Sigmund Freud considered the possibility of the operation of tendencies beyond the pleasure principle and theorised a potential over-riding of the pleasure principle that involves an access of pleasure through pain. I use the term here to interrogate the possibilities of how Ginsberg attempts at queering the pain-pleasure principle by portraying the agency of homosexual acts and queer performativity in a way that transforms a Freudian 'unpleasure' into queer 'pleasure.'

ii The idea that the construct of gender is constructed through repetitive performance of gender is central to the concept of 'gender performativity' in Judith Butler's Gender Trouble: Feminism and the Subversion of Identity (2002).

iii See page 194 of Butler's Gender Trouble where she uses Adrienne Rich's notion of 'compulsory heterosexuality' to theorise upon the term 'heterosexual matrix' that characterises "a hegemonic discursive/epistemic model of gender intelligibility that assumes that for bodies to cohere and make sense, there must be a stable sex expressed through a stable gender that is oppositionally and hierarchically defined through the compulsory practice of heterosexuality."

${ }^{\text {iv }}$ See pages 94 and 110 of Michel de Certeau's The Practice of Everyday Life (1984) for his theorisation of the agency of the potential liminality of urban spaces.

v See page 3 of Stephen Heath's The Sexual Fix (1982) where he identifies the ideology of sexual revolution as a discourse that eventually limits the subversive conceptualisations of sexual non-conformity. He identifies the discourse of sexual revolution as a phallocentric construction that 'fixes' men's and women's social roles in given constructs of sexual misrepresentation.

${ }^{\text {vi }}$ For a discussion on Gilles Deleuze and Félix Guattari's idea of 'Minor Literature' and 'minoritarian politics' in literature, see chapter 6 of Claire Colebrook's critical commentary in Gilles Deleuze (2007).

\section{References}

Bell, D. \& Valentine, G. (1995). Introduction: Orientations. In D. Bell \& G. Valentine (Eds.), Mapping desire: Geographies of sexualities (pp. 1-24). London: Routledge.

Breslin, J. (1977). Allen Ginsberg: The origins of 'Howl' and 'Kaddish'. The Iowa Review, 8(2),82-108.

Retrieved from http://www.jstor.org/stable/20158746

Butler, J. (2002). Gender trouble: Feminism and the subversion of identity. London: Routledge.

Butler, J. (1997). The psychic life of power: Theories in subjection. Stanford: Stanford University Press.

Butler, J. (2004). Undoing gender. New York: Routledge.

Colebrook, C. (2007). Gilles Deleuze. New York: Routledge.

de Certeau, M. (1984). The practice of everyday life. Berkeley: University of California Press.

Fone, B. (2000). Homophobia: A history. New York: Picador. 
Ginsberg, A. (2007). Collected poems, 1947-1997. New York: HarperCollins Publishers.

Ginsberg, A. (2009). Howl, Kaddish and other poems. London: Penguin Books.

Ginsberg, A. \& Miles, B. (Eds.). (2006). Howl: Original draft facsimile, transcript, and variant versions, fully annotated by author, with contemporaneous correspondence, account of first public reading, legal skirmishes, precursor texts, and bibliography. New York: Harper Perennial Modern Classics.

Hartman, A. (2005). Confessional counterpublics in Frank O'Hara and Allen Ginsberg. Journalof Modern Literature, 28(4), 40-56. Retrieved from http://muse.jhu.edu/journals/jml/summary/vo28/28.4hartman.html

Heath, S. (1982). The sexual fix. Basingstoke: Macmillan.

Knopp, L. (1995). Sexuality and urban space: A framework for analysis. In D. Bell \& G. Valentine (Eds.), Mapping desire: Geographies of sexualities (pp. 136-146). London: Routledge.

Laplanche, J. \& Pontalis, J. (1988). The language of psychoanalysis. London: Karnac Books.

Meyer, L. \& Ginsberg, A. (1997). Interviewing Allen Ginsberg. The American Poetry Review, 26(4), 21-23. Retrieved from http://www.jstor.org/stable/27782469

Musser, A. J. (2005). Masochism: A queer subjectivity. Women, Gender E Sexuality Studies Research, 17. Retrieved from http://openscholarship.wustl.edu/wgss/17

Raskin, J. (2004). America scream: Allen Ginsberg's Howl and the making of the beat generation. Berkeley: University of California Press.

Selby, N. (1996). Allen Ginsberg's 'Howl': Sexuality and popular heroism in 50s. Revue française d'etudes américaines, 68, 62-70. Retrieved from http://www.jstor.org/stable/20874288

Stimpson, C. R. (1983). The beat generation and the trials of homosexual liberation.Salmagundi, 58 (59), 373-392. Retrieved from http://www.jstor.org/stable/40547579

Thanem, T \& Wallenberg, L. (2010). Buggering Freud and Deleuze: Towards a queer theory of masochism. Journal of Aesthetics \& Culture, 2. doi: 10.3402/jac.v2io.4642

Van Engen, D. (2012). Howling masculinity: Queer social change in Allen Ginsberg's poetry.The Graduate Consortium in Women's Studies: Gender, Sexuality and Urban Spaces Conference 2011 Working Papers Collection, 1-15. Retrieved from http://web.mit.edu/gcws/pdf/2012ConfPub-

Final\%2odesign\%2oPDFS/VanEngen_final.pdf 